\title{
Effect of defaunation and amino acid supplementation on growth and amino acid balance in growing sheep
}

\author{
WG Fahmy 1, MR Murphy 2 \\ 'Department of Animal and Fish Production, Faculty of Agriculture, Alexandria University, Alexandria, Egypt ; \\ 2Department of Animal Sciences, College of Agriculture, University of Illinois, 61801 Urbana, USA
}

\begin{abstract}
Defaunation usually increases the efficiency of the utilization of different food components which lead to an increase in bacterial protein synthesis. It has been reported by different authors that defaunation lead to an increase in the rate of growth of growing animals, and the wool growth. The supplementation with protected amino acids may increase the growth rate and may lead to increase the efficiency of nitrogen utilization.
\end{abstract}

Twenty-eight sheep (average body weight $30 \mathrm{~kg}$ ) have been used in this present trial in order to evaluate the effect of defaunation using the alkanate 3SL32 and the addition of protected methionine and lysine on animal growth and amino acids digestibility in the body of growing sheep. Animal was offered $14.7 \mathrm{~g}$ amino acid mixture containing $10.4 \%$ methionine and $31.7 \%$ lysine per $\mathrm{kg} \mathrm{DMl}$.

Animals has been defaunated using three doses of defaunating agents and defaunated animals are isolated from normal animals to be kept free from protozoa. Defaunated animais are examined two times per week to be sure that the rumen is free from protozoa.

Animal has been divided to two groups control and determined, each group was divided to two subgroups receiving control diet (diet I) containing $17.3 \% \mathrm{CP}$ and supplemented diet (diet II) containing $17.9 \% \mathrm{CP}$. Rate of growth was determined during the growth trial each week for 9 weeks. Amino acids were determined in feed, blood, wool and feces in order to calculate the amino acid balance in tested animals.

Result obtained showed that the defaunation increases the rate of growth of growing lambs in addition to the supplementation with protected amino acids increase the growth rate and feed conversion efficiency. The surprising result was the low growth rate of control group fed diet II, but this could be due to the fact that the presence of protozoa decreases the nitrogen flow to the duodenum, and this decrease varies from $5 \%$ to $100 \%$ depending on the content of diets from cell wall constituents (Jouany et al, 1988, Meyer et al, 1986).

Amino acids digestibility was affected by both treatments defaunation or amino acids supplementation where the difference was significant, the normal group fed diets (II) show the highest values of digestibility and in the same time the highest content of amino acids in wool, while the concentration of amino acids in plasma was significant due to the defaunation.

Data were analyzed by the method of least square mean analysis of variance using the GLM procedure of the SAS (1982)

In conclusion, defaunation lead to an increase in animal performance, supplementation with protected amino acid lead to an increase in animal performance in the case of defaunated animals and did not show an improvement in animal performance with the control animals.

\begin{tabular}{llcccccc}
\hline Diet & Treatment & $\begin{array}{c}\text { Initial } \\
\text { weight } \\
(\mathrm{kg})\end{array}$ & $\begin{array}{c}\text { Protozoal } \\
\text { population } \\
(\times 105 / \mathrm{ml})\end{array}$ & $\begin{array}{c}\text { Feed } \\
\text { intake } \\
\text { (g DM/day) }\end{array}$ & $\begin{array}{c}\text { Live } \\
\text { weight gain } \\
\text { (g/day) }\end{array}$ & $\begin{array}{c}\text { Feed conversion } \\
\text { efficiency } \\
\text { (g DMI/g growth) }\end{array}$ & $\begin{array}{c}\text { Wool } \\
\text { growth } \\
\text { (g/day) }\end{array}$ \\
I & Control & 30 & 4.5 & $1063.5^{\mathrm{a}}$ & $115.7^{\mathrm{a}}$ & $9.19^{\mathrm{a}}$ & $9.6^{\mathrm{a}}$ \\
I & Defaunated & 30 & - & $870^{\mathrm{a}}$ & $130.6^{\mathrm{a}}$ & $6.79^{\mathrm{b}}$ & $8.5^{\mathrm{a}}$ \\
II & Control & 30 & 4.5 & $92^{\mathrm{a}}$ & $70^{\mathrm{b}}$ & $14.02^{\mathrm{c}}$ & $8.7^{\mathrm{a}}$ \\
II & Defaunated & 30 & - & $1005^{\mathrm{a}}$ & $180.8^{\mathrm{c}}$ & $5.56^{\mathrm{b}}$ & $10.1^{\mathrm{a}}$
\end{tabular}

$a, b, c$ means in the same colums without a common letter in their superscripts differ $(P<0.05)$; Diet (I) without amino acid addition ; Diet (II) with amino acid addition 